\author{
Cornelia SAHLING \\ Postgraduate of International Economic Relations Dept. \\ Peoples' Friendship University of Russia \\ 6 Miklukho-Maklaya St., Moscow, Russia, 117198 \\ Phone: (495) 434-43-15 \\ e-mail: cornelia.sahling@gmail.com
}

\title{
Interdependence of the European Central Bank's Policy and Financial Stability in the Eurozone
}

\begin{abstract}
The paper investigates the influence of the European Central Bank's (ECB) policy on financial stability in the Eurozone and proves that before the world financial crisis of 2008-2009 and the European debt crisis, the ECB did not pay enough attention to the maintenance of financial stability. The author evaluates main ECB crisis measures and their impact on financial stability and argues that the unconventional monetary policy measures contributed to economic recovery, but they did not result in complete stabilisation of the European financial system. Moreover, according to the author, the ECB's non-standard measures failed to fulfil the conditions required for acting as a lender of last resort, what continues to threaten the financial stability. In the context of heterogeneity of the Eurozone countries and global financial challenges, the difficulties of maintaining financial stability are principally related to the common currency and the single monetary policy.
\end{abstract}

JEL classification: F36

Keywords: Eurozone; financial stability; European Central Bank; price stability; non-standard monetary policy measures.

\section{Introduction}

$T$ he consequences of the world financial crisis of 2008-2009 and the European debt crisis unfolding from the late 2009, as well as the slow recovery of the Eurozone countries, stimulated interest in the issues of financial stability. Pre-crisis institutions were not able to ensure financial stability when market mechanisms failed and structural contradictions appeared in the Eurozone. Generally, the Eurozone is characterized by quite intensive cross-border activities of banks due to the integration of financial markets. This affects financial stability, because greater mobility of foreign capital contributes to vulnerability to external shocks and increases banks' interdependence [9. P. 50].

Except for the structural and functioning specifics of the monetary union, challenges of global financial system development also add to the vulnerability to external shocks. These challenges encompass institutional peculiarities of the global financial architecture, considerable significance of small number of large financial institutions, shadow finances, and rapid spread of financial problems in the global economy [2. P. 104-105]. At the same time, in the world financial system there emerged certain imbalances between the established rules of international regulation and the processes of financial globalization [1. P. 2]. The above-mentioned aspects can be considered destabilizing factors for the financial system of the euro area.

The European Central Bank (ECB) understands financial stability as the ability of the financial system to withstand shocks without disrupting its financial intermediation function ${ }^{1}$.

${ }^{1}$ Spotlight on financial stability. ECB. Available at: https://www.ecb.europa.eu/explainers/tell-memore/html/financial_stability.en.html. 
The specifics of the euro area financial system also play an important role in financial stability. In conditions of the common currency, integration of the national financial markets and banking systems, the interdependence of the national financial systems becomes stronger and crises unfold faster. During the pre-crisis period, the responsibility for providing financial stability and financial supervision was largely assigned to national institutions. This directly contradicted a single monetary policy in 19 heterogeneous countries without a possibility to determine national exchange rates.

The aforementioned factors should have made the ECB pay particular attention to the maintenance of financial stability. Yet actually in pre-crisis period, the regulator's main objective was maintaining price stability. With this end in view, the research of the interdependence of the policy implemented by the ECB and financial stability appears to be quite relevant. The paper aims to identify the directions for developing the ECB policy and study the impact of this policy on the financial stability in the euro area.

\section{Maintenance of financial stability in the pre-crisis period}

Before the crisis, the ECB policy aimed for the only one fundamental target, namely, maintaining price stability. According to the ECB, the harmonized index of consumer prices (HICP) in the euro area should be below, but close to $2 \%$. At this, the ECB is politically independent in decision-making. The research demonstrated that the independence of central banks is conducive to keeping the inflation rates low [8. P. 151-162]. In the pre-crisis period, the regulator was supposed to do everything possible to ensure the financial stability by maintaining price stability; other regulatory and supervisory bodies bore main responsibility for providing financial stability [11. P. 194].

Indeed, in conditions of high inflation it is impossible to imagine a stable financial system. Yet the focus on price stability during the monitoring of the money supply contributed to the inconspicuous development of crisis phenomena in the euro area. In the pre-crisis period (until the fall of 2007), the level of the HICP did not deviate significantly from the $2 \%$ mark, but in the same period there was also a significant increase in the M3 measure of money supply (see Figure). The growth of money supply did not indicate the danger of a sharp increase in consumer prices. It indicated a forming bubble in asset markets (stocks markets, real estate markets and commodities markets) and an increase in asset inflation [11. P. 203].

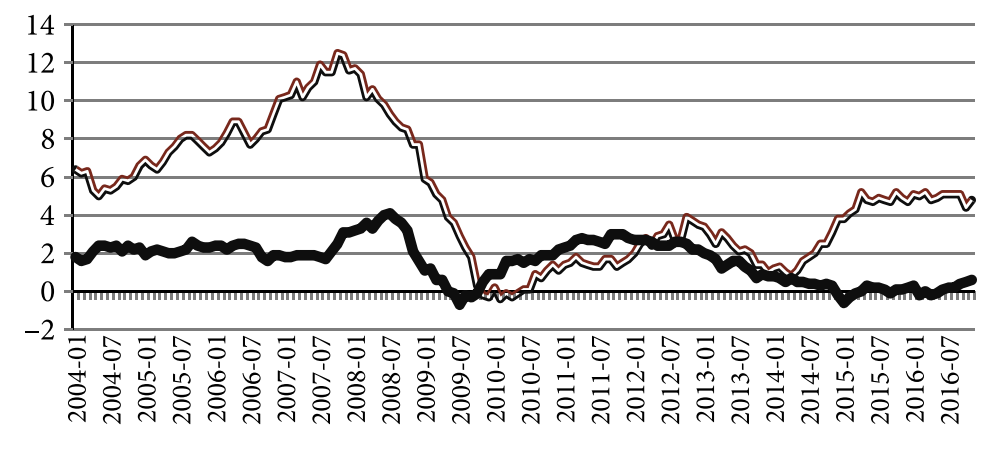

\33, rate of change $\longrightarrow$ HIPC, rate of change

Money supply and HICP in the Eurozone in 2004-2016,$\%$

${ }^{1}$ Compiled using the ECB statistics. Available at: http://sdw.ecb.int/quickview.do?trans=N\&start= \&submitOptions. $y=0 \&$ submitOptions. $\mathrm{x}=0$ \&end=\&SERIES_KEY=117.BSI.M.U2.Y.V.M30.X.I.U2.2300. Z01.A\&periodSortOrder=ASC; http://sdw.ecb.int/quickview.do?SERIES_KEY=122.ICP.M.U2.N.00000 0.4.ANR\&periodSortOrder=ASC. 
In other words, when tracking the HICP in the euro area, the ECB overlooked the development of the bubble, and therefore, failed to ensure financial stability in the euro area. However, it is certain that even with the shifted emphasis in the ECB policy from keeping price stability to ensuring financial stability, it can be very difficult to track the impending formation of a bubble. The priority of the goal of financial stability is also ambiguous. It can contradict other goals of central banks and incur a moral risk because of the large banks' conviction about immediate help from central banks in vulnerable situations [12. P. 6-7].

\section{The ECB's crisis measures for promoting financial stability in the euro area}

The taken crisis measures were not able to restore financial stability in the euro area quickly. It has already been mentioned that to maintain financial stability, according to the ECB, the financial system should keep on fulfilling its intermediation function. However, in the euro area, despite large-scale crisis measures and quite substantial reduction of interest rates, lending to non-financial sector is still below pre-crisis levels [5. P. 34-36]. With the development of the debt crisis, the segmentation of the interbank market intensified, the risk premiums and long-term interest rates for the most crisis-hit countries increased greatly, what adversely affected the availability of loans [10. P. 280-281]. All this necessitated the adoption of additional measures by the ECB.

Because of the insufficient efficiency of the traditional monetary policy, the ECB switched to non-standard instruments of monetary policy. Most of these measures have been widely implemented since the end of 2011. Professor V. Usoskin argues that non-standard measures differ from the crisis measures employed earlier in that the ECB's interventions became more active and aimed at increasing the consumer and investment demand in the real sector of the euro area [6. P. 15]. Another important characteristic of unconventional policy is its impact on central banks' balance sheets. Conducted monetary expansion leads to a change in the size, structure and risk indicators of the central banks' balance sheets [6. P. 13].

The main unconventional policy measures include the purchase of securities in the secondary market, long-term financing of the banking sector through the ECB, a significant cut in interest rates, waiving of the requirements for banks within the refinancing policy, and outright monetary transactions (Table 1).

Table 1

\section{Characteristics of the ECB's main non-standard crisis measures}

\begin{tabular}{|c|c|c|}
\hline Measure & Period & Characteristics \\
\hline $\begin{array}{l}\text { Purchase of } \\
\text { securities in the } \\
\text { secondary market }\end{array}$ & Since 2009 & $\begin{array}{l}\text { Various asset purchase programmes (APP) for public and private } \\
\text { sector }\end{array}$ \\
\hline \multirow{2}{*}{$\begin{array}{l}\text { Long-term } \\
\text { financing of the } \\
\text { banking sector } \\
\text { through the ECB }\end{array}$} & $\begin{array}{l}\text { Since late } \\
2011\end{array}$ & $\begin{array}{l}\text { Longer-term refinancing operations, LTROs (provide financing } \\
\text { for periods up to three years) }\end{array}$ \\
\hline & $\begin{array}{l}\text { Since } \\
\text { mid-2014 }\end{array}$ & $\begin{array}{l}\text { Targeted longer-term refinancing operations, TLTROs (provide } \\
\text { financing for periods up to four years) }\end{array}$ \\
\hline $\begin{array}{l}\text { Gradual reduction } \\
\text { of interest rates }\end{array}$ & Since 2008 & $\begin{array}{l}\text { Change of the main refinancing rate: from } 3.75 \% \text { in October, } \\
2008 \text { to } 0 \% \text { in March, } 2016 \text {. } \\
\text { Change of the deposit facility rate for the Eurosystem banks: } \\
\text { from } 3.25 \% \text { in October, } 2008 \text { to }-0.4 \% \text { in March, } 2016\end{array}$ \\
\hline $\begin{array}{l}\text { Easing the } \\
\text { refinancing policy }\end{array}$ & $\begin{array}{l}\text { Since the fall } \\
\text { of } 2008\end{array}$ & $\begin{array}{l}\text { Approving all banks' requests for funds in the ECB auctions; } \\
\text { Waiving requirements to assets accepted as collateral by the ECB }\end{array}$ \\
\hline $\begin{array}{l}\text { Outright monetary } \\
\text { transactions }\end{array}$ & Since 2012 & $\begin{array}{l}\text { The ECB's promise to buy out government bonds in an unlimited } \\
\text { amount if such need arises. } \\
\text { The program is in effect, but the ECB has not made use of it yet }\end{array}$ \\
\hline
\end{tabular}


Providing liquidity to banks through long-term financing, easing the ECB's refinancing policy and redeeming securities should not only have rectified the situation in banks, but also have increased lending to the real sector of the economy, and, thereby, have improved the overall economic environment. The cut in interest rates in the euro area should have contributed to this goal as well.

An important issue is the impact of non-standard crisis measures on financial stability. If we proceed from the above-mentioned understanding of the financial stability, which implies fulfilling all functions of the financial system concerning financial intermediation, it is difficult to talk about the complete restoration of the financial stability in the euro area, especially when bank lending continues to decrease compared to the pre-crisis period. In addition, the artificial retention of extremely low interest rates by the ECB can adversely affect financial stability, because it distorts the flexibility of financial markets and free pricing of loans [14. P. 159-160].

However, if interpreting financial stability in a broader sense, we can talk about stabilization of the situation, which can be attributed to the fact that the level of interest rates has dropped, including 10-year government bonds. This is true for Greece and Portugal, which are among the countries most affected by the crisis. The interest rate on 10 -year government bonds fell in Greece from 22.5\% in 2012 to 8.4\% in 2016, and in Portugal it went down from $10.6 \%$ to $3.2 \%$ respectively ${ }^{1}$. Some macroeconomic indicators of the euro area countries have improved compared to the peak of the financial crisis of 2008-2009 and the peak of the European debt crisis of 2010-2011. From the second quarter of 2010 to the second quarter of 2016 , the budget deficit of the euro area countries decreased from $-6.3 \%$ to $-1.8 \%^{2}$; however, over the same period of time the government debt increased from $81.5 \%$ to $91 \%$ of GDP ${ }^{3}$. In general, we can point to some improvement in the economic situation, though the indicators of the pre-crisis period have not yet been achieved.

The dissimilarity of macroeconomic indicators in the euro area countries caused by the crisis played its part in strengthening financial instability. The trend for exacerbating imbalances between countries is rather dangerous, because it leads to the conflict of national interests. In such conditions, the ECB policy cannot maintain complete stability, because it proves to be efficient only for part of the countries.

A positive aspect is a trend for some recovery of the banking sector in the euro area. The banks have tackled the liquidity problem, the interest rates have dropped, and the confidence in the banking system has been revived. In November, 2014, the ECB started supervising significant banks in the euro area. The Single Supervisory Mechanism, which supervises the largest and most important banks in the euro area directly at European level, was created within the framework of the Banking Union organized in 2012 as a response to the financial crisis.

The latest list of significant banks in the Eurozone was published in November, 2016 and includes 127 financial organizations. Among the banks identified as significant there are, for instance, Deutsche Bank, Banco Santander, BNP Paribas, Crédit Agricole, Société Générale. To qualify as significant, a bank must fulfil at least one of the following four criteria:

- size of assets: the total value of its assets exceeds 30 billion euros;

- economic importance: for the specific country or the EU economy as a whole;

- cross-border activities: the total value of the assets exceeds 5 billion euros and the ratio of the cross-border assets/liabilities in more than one other participating Member State to the total assets/liabilities is above $20 \%$;

${ }^{1}$ Official website of the ECB. Available at: https://www.ecb.europa.eu/stats/money/long/html/index. en.html.

${ }^{2}$ Official website of the ECB. Available at: http://sdw.ecb.int/quickview.do?SERIES_KEY=325. GFS.Q.N.I8.W0.S13.S1._Z.B.B9._Z._Z._Z.XDC_R_B1GQ_CY._Z.S.V.CY._T.

${ }^{3}$ Official website of the ECB. Available at: http://sdw.ecb.int/quickview.do?SERIES_KEY=325. GFS.Q.N.I8.W0.S13.S1.C.L.LE.GD.T._Z.XDC_R_B1GQ_CY._T.F.V.N._T. 
- direct public financial assistance: it has requested or received funding from the European Stability Mechanism or the European Financial Stability Facility ${ }^{1}$.

In line with its responsibility for financial supervision in the euro area, the ECB monitors the relevant financial stability indicators of significant banks. The data published for significant banks in the euro area reveal an increase in the share of equity, which is consistent with the stated goal for the implementation of Basel III in the EU. Yet the profitability of both equity and assets remains low and even has decreased compared to 2015 (Table 2).

Table 2

Key performance indicators of significant institutions in the euro area, \%

\begin{tabular}{|l|c|c|c|c|c|}
\hline \multicolumn{1}{|c|}{ Indicator } & Q2 2015 & Q3 2015 & Q4 2015 & Q1 2016 & Q2 2016 \\
\hline Return on equity & 6.16 & 5.70 & 4.41 & 5.13 & 5.36 \\
\hline Return on assets & 0.37 & 0.34 & 0.28 & 0.32 & 0.33 \\
\hline Total capital ratio (Tier 1 + Tier 2) & 15.84 & 16.06 & 16.85 & 16.65 & 16.93 \\
\hline
\end{tabular}

Source: Supervisory Banking Statistics of the ECB. Available at: https://www.bankingsupervision. europa.eu/banking/statistics/html/index.en.html.

A substantial gap in financial performance indicators between countries remains a threat to the financial stability in the euro area. The Table 3 shows that the performance indicators of significant banks in Portugal have the lowest values. In terms of return on both equity and assets, banks in Slovenia hold the leading position, and as for the total capital ratio, the leaders are the banks from Finland (Table 3). This gap between the performance indicators proves that the averages do not reflect the real situation in the banking sector. For example, the return on capital in Slovenia is $39.2 \%$, while in Portugal it is completely negative $(-4.7 \%)$, while the average for the euro area is $5.4 \%$.

Overall efficiency of crisis measures is confirmed by experts estimates. For instance, P. Praet, Member of the Executive Board of the ECB, feels quite confident about general efficiency of the implemented policy. In the mid-2014, the ECB introduced additional non-standard measures against the backdrop of continuing deflation in the euro area (see Figure). To maintain price stability the ECB initiated a series of targeted longer-term refinancing operations (TLTROs), set the negative deposit facility rate (DFR), and extended the asset purchase programme (APP). In the absence of these non-standard measures, the inflation in the euro area would have been negative in 2015, and in 2016, it would have been around half a percentage point lower than actually observed in $2017^{2}$. These measures had a positive impact on the price stability and thus enhanced the financial stability in the euro area.

At the same time, it is necessary to take into consideration that a long period of extremely low interest rates and provision of liquidity to banks will not necessarily contribute to financial stability in the euro area. The president of the German Bundesbank J. Weidmann is certain that the longer the unconventional monetary policy is being adopted, the lower its efficiency is going to be $\mathrm{b}^{3}$. Further decrease of low and partly negative interest rates does not strengthen the banking sector. Conversely, the low level of interest rates combined with long-drawn-out recovery resulted in falling profits of the banks in the euro area ${ }^{4}$, what can potentially harm

${ }^{1}$ What makes a bank significant? The ECB. Available at: https://www.bankingsupervision.europa. eu/banking/list/criteria/html/index.en.html.

${ }^{2}$ Praet P. The ECB's monetary policy response to disinflationary pressures. Speech by Peter Praet at ECB and its Watchers XVII conference, 7 April 2016. Available at: https://www.ecb.europa.eu/press/key/ date/2016/html/sp160407.en.html.

${ }^{3}$ Weidmann J. Wie können wir den wirtschaftlichen Herausforderungen des Euro-Raums begegnen? Rede auf dem 25. Europäischen Bankenkongress, 20. November 2015. Available at: https://www. bundesbank.de/Redaktion/DE/Reden/2015/2015_11_20_weidmann.html.

${ }^{4}$ European Central Bank. Financial Stability Review. May 2016, p 5. 
the financial stability, because banks in such situation are interested in using risky financial instruments. Relying on them heightens the systemic risk in banking sector, which was one of the reasons behind the development of the financial crisis of 2008-2009.

Table 3

Key performance indicators of significant institutions in the euro area, by country, Q2 2016, \%

\begin{tabular}{|l|c|c|c|}
\hline \multicolumn{1}{|c|}{ Country } & Return on equity & Return on assets & Total capital ratio \\
\hline Belgium & 7.80 & 0.35 & 19.26 \\
\hline Germany & 2.73 & 0.13 & 17.78 \\
\hline Estonia & $\mathrm{C}$ & $\mathrm{C}$ & $\mathrm{C}$ \\
\hline Ireland & 9.16 & 1.07 & 20.98 \\
\hline Greece & $\mathrm{C}$ & $\mathrm{C}$ & 18.02 \\
\hline Spain & 6.78 & 0.51 & 14.31 \\
\hline France & 7.44 & 0.43 & 17.19 \\
\hline Italy & 2.21 & 0.16 & 15.14 \\
\hline Cyprus & 6.89 & 0.73 & 15.77 \\
\hline Latvia & 18.89 & 1.99 & 19.64 \\
\hline Lithuania & 11.22 & 1.18 & 19.84 \\
\hline Luxemburg & 6.47 & 0.53 & 19.56 \\
\hline Malta & 12.85 & 0.92 & 14.85 \\
\hline Netherlands & 7.91 & 0.41 & 21.36 \\
\hline Austria & 7.67 & 0.59 & 16.45 \\
\hline Portugal & -4.68 & -0.34 & 11.9 \\
\hline Slovenia & 39.24 & 5.40 & 20.08 \\
\hline Slovakia & - & - & 24.17 \\
\hline Finland & 8.49 & 0.42 & - \\
\hline
\end{tabular}

Notes:

1. C: the value is suppressed for confidentiality reasons.

2. There are no significant institutions at the highest level of consolidation in Slovakia.

Source: European Central Bank. Supervisory Banking Statistics. Second quarter 2016. November 2016, pp. 20; 46.

The assessment of efficiency of the ECB's crisis measures is complicated by significant heterogeneity of the Eurozone countries. This is one of the essential contradictions of the euro area financial system. The ECB is not able to meet all countries' interests through its single monetary policy. The ECB's activities are largely oriented towards the model of the German Bundesbank. However, according to the Russian researchers A. Bazhan and K. Gusev, the problem is that this model functioned in highly developed market economy, whereas in other countries (first and foremost, South European ones) the national central banks performed a more prominent role in the formation of national financial markets, ensuring better balance of payments, and influencing lending volumes [3. P. 96]. Because of the implementation of a single monetary policy and introduction of a common currency, the South European countries could no longer use their normal methods of crisis regulation. Therefore, it is not surprising that it will take these countries more time to solve the crisis.

\section{The ECB and its role as a lender of last resort}

To maintain financial stability in the Eurozone it is important to ensure the trust of its participants. It was the mistrust that exacerbated the situation with the countries most affected by crisis (Greece, Portugal, Spain and Ireland) and triggered the flight of capital from them, as well as the increase in interest rates on these countries' government bonds. 
In a national state, there are no doubts that, if necessary, the national central bank will act as a lender of last resort. Acting as a lender of last resort and providing banks with liquidity, the central bank can contribute to financial stability, when banks have difficulties with obtaining sufficient borrowing [13. P. 3]. For the ECB the situation is somewhat different. It is a supranational body for different states, each of which has its own national interests. Accordingly, the countries most affected by the crisis, mainly the South-European ones, are interested in financing their deficits, whereas more economically prosperous countries do not want the ECB as a supranational body to assume financial responsibility for government securities with a low credit rating. In addition to diverse and partly contradictory interests of the euro area countries, the role of the lender of last resort is impeded by the very mandate of the ECB. Article 123 of the Lisbon Treaty forbids the ECB to directly lend to governments; this is not within its competence.

Scientific literature puts forward certain constraints for central banks to be successful in their role of lender of last resort. However, national central banks are supposed to play this role only during crisis. These constraints include:

- lending only to solvent banks;

- lending on good collateral (i.e. liquid tradable securities);

- lending at a high (actually, penalty) rate relative to normal market rates [15. P. 248].

If considering these criteria in the context of the ECB policy, it can be established the main crisis measures contradict them. As the crisis developed, the ECB had been gradually changing its refinancing policy and finally had waived its requirements for provided collateral. Hence, banks could put up securities with low investment ratings, as well as governmentguaranteed securities as collateral for the ECB. It is also not possible to speak about "penalty" rates; conversely, the ECB had been steadily reducing its interest rate (see Table 1).

In such conditions, the financial stability is not maintained, because there arises a moral risk for banks. When the liquidity is provided by the central banks, the banks have no incentive to abandon many risky financial products, because they will count on the support in the event of a repeat of the crisis scenario. Banks get used to the central banks' cheap loans and do not switch again to alternative sources of financing, which they used before the crisis. Moreover, the ECB is not protected against possible losses associated with the operations conducted. In case of a default on securities purchased previously by the ECB, the regulator will suffer losses on these securities. It means that these losses can be distributed among the national central banks of the euro area, which all contributed their share to the capital of the ECB .

\section{Modern approach of the ECB to maintaining financial stability in the euro area}

The identification of the risks to financial stability is complicated by the heterogeneity of potential threats to the financial security, the diffusion of crisis phenomena between different segments of financial markets and the non-linear nature of the factors' impact on the financial system [7. P. 57]. When identifying the risks to financial stability in the euro area, the ECB's analysts should take into account not only the macroeconomic development of the euro area countries and the trends in the performance indicators of the euro area financial system but also the global challenges of the world financial system.

A precautionary measure of the ECB to ensure the financial stability is the monitoring the situation in the euro area. Since 2004, the ECB has been publishing the Financial Stability Review twice a year. The report highlights the main risks to financial stability in the euro area. The findings of the November 2016 Report suggest that the main threats to financial stability include global risks, vulnerability of the banking sector, high level of debt and higher risks in the investment fund sector in the euro area. The first risk factor is connected with political uncertainty, which exists due to such events as the referendum in the United Kingdom in favor

${ }^{1}$ Capital subscription. The ECB. Available at: https://www.ecb.europa.eu/ecb/orga/capital/html/index.en.html. 
of Brexit and the conducted elections in the USA with the election of D. Trump as president. Other global challenges encompass slowing down of developing countries' economic growth and the instability in their markets. The second risk factor is related to the problems of the banking sector, namely low profitability and high stocks of non-performing assets. The third factor results from the high level of sovereign debt and the debt of the non-financial private sector. This poses risks to financial stability in conditions of low economic growth. The fourth risk factor linked with the investment funds may be exacerbated by their increased risk readiness in the current low interest rate environment in the euro area.

The ECB's analysts are afraid of the risks'transition to different sectors of the financial system if the above-mentioned risk factors strengthen. It is necessary to take into account that imbalances in various sectors of the financial system can be quickly transmitted to other segments through the multiplication of negative economic phenomena [4. P. 109]. The negative effect on financial stability in the euro area can be produced not only by regional shocks, but also by global challenges in the world financial markets and by the destabilization of the world financial system. At the same time, the ECB policy can only have a very limited impact on these risk factors, what narrows the European regulator's ability to maintain financial stability in the Eurozone.

\section{Conclusion}

The analysis of some aspects of the ECB policy (particularly, of non-standard measures of monetary policy) enabled us to make the following conclusions regarding the maintenance of financial stability in the euro area:

1. In the pre-crisis period, the European regulator paid insufficient attention to the issues of the financial stability. Pursuing just one main goal, specifically, maintaining price stability, undoubtedly contributed to the inconspicuous development of the crisis. Gradual emergence of risks to financial stability in the euro area is confirmed by a significant growth of the money supply with the inflation rate remaining fairly stable.

2. The provided characteristics of the key non-standard monetary policy measures and assessment of their impact prove that the ECB policy was not able to completely restore financial stability.

3. The crisis policy implemented by the ECB does not satisfy the criteria set for a lender of last resort. In the event of a repeated exacerbation of the crisis situation, the ECB will not be able to efficiently restore financial stability by following its current policy due to the moral risk.

4. Except for the problems of the banking sector and high level of debt the ECB considers global risks to be among serious risk factors in maintaining financial stability in the euro area. The findings of the analysis reveal that in the future it will be necessary to develop additional preventive measures and further improve financial regulation and supervision to enhance financial stability in the euro area.

\section{References}

1. Andronova N. Ye. Mesto i rol' stran BRIKS v formirovanii novoy paradigmy mirovoy finansovoy arkhitektury XXI v. [BRICS in the formation of a new paradigm of global financial architecture of the $21^{\text {st }}$ century]. Innovatsionnaya ekonomika - Innovative Economy, 2017, no. 1(10). Available at: http://193.232.218.56/web-local/fak/rj/index.php?id $=25 \& \bmod =$ rubric $\& \mathrm{~mm}=30$.

2. Arkhipova V.V. Institutsional'nye istochniki finansovoy nestabil'nosti [Institutional sources of financial instability]. Sovremennaya Yevropa - Contemporary Europe, 2016, no. 5, pp. 103-114.

3. Bazhan A.I., Gusev K.N. Evropeiskii tsentral'nyi bank v usloviyakh finansovogo krizisa [European Central Bank in conditions of financial crisis]. Sovremennaya Yevropa Contemporary Europe, 2016, no. 3, pp. 93-103. 
4. Pilipenko O.I. Ekonomicheskie shoki i tsiklicheskoe razvitie natsional'nykh finansovykh sistem [Economic shocks and cyclical development of national financial systems]. Vestnik RUDN. Seriya Ekonomika - Bulletin of Peoples' Friendship University of Russia. Series: Economics, 2015, no. 1, pp. 103-111.

5. Strenina M. A., Sahling C. Problemy bankovskogo sektora zony evro v usloviyakh mirovogo finansovogo krizisa [Challenges for the Eurozone banking sector after the global financial crisis]. Vestnik RUDN. Seriya Ekonomika - Bulletin of Peoples' Friendship University of Russia. Series: Economics, 2016, no. 1, pp. 32-41.

6. Usoskin V. M. "Nestandartnaya" monetarnaya politika: metody i rezul'taty [Unconventional monetary policy: Methods and results]. Dengi i kredit - Money and credit, 2016, no. 11, pp. 12-18.

7. Yakovlev I.A., Kabir L.S., Nikulina S.I., Rakov I.D. Regional'nye finansovye mekhanizmy i ikh rol' v obespechenii finansovoi stabil'nosti (opyt ASEAN) [Regional financial mechanisms and their role in financial stability ensuring (experience of ASEAN)]. Nauchnoissledovatel'skii finansovyi institut. Finansovyi zhurnal - Financial Research Institute. Financial Journal, 2016, no. 5, pp. 52-62.

8. Alesina A., Summers L.H. Central Bank Independence and Macroeconomic Performance: Some Comparative Evidence. Journal of Money, Credit and Banking, 1993, vol. 25, no. 2, May, pp. 151-162.

9. Allen F., Beck T., Carletti E., Lane P.R., Schoenmaker D., Wagner W. Cross-Border Banking in Europe: Implications for Financial Stability and Macroeconomic Policies. London: Centre for Economic Policy Research, 2011.

10. Casiraghi M.; Gaiotti E., Rodano L., Secchi A. ECB Unconventional Monetary Policy and the Italian Economy during the Sovereign Debt Crisis. International Journal of Central Banking, 2016, vol. 12, no. 2, June, pp. 269-315.

11. Grauwe P., de. Economics of Monetary Union. $11^{\text {th }}$ ed. Oxford University Press, 2016.

12. Ferguson R. W. Should Financial Stability Be an Explicit Central Bank Objective? Challenges to Central Banking from Globalized Financial Systems: Proc. of the Conference at the IMF (Washington, D.C., September 16-17, 2002). Available at: https://www.imf.org/external/ pubs/ft/seminar/2002/gfs/eng/ferguson.pdf.

13. Steinbach A. The Lender of Last Resort in the Eurozone. Common Market Law Review, 2016, vol. 53, no. 2, pp. 361-384. Available at:http://ggcpp.nuff.ox.ac.uk/wp-content/uploads/2016/02/Armin-WP-The-Lender-of-Last-Resort-in-the-Eurozone.pdf.

14. Tsionas E. G. The Euro and International Financial Stability. Financial and Monetary Policy Studies, vol. 37. Springer International Publishing, 2014.

15. Wall L. D. Central Banking for Financial Stability. Some Lessons from the Recent Instability in the US and Euro Area. Japan Ministry of Finance Public Policy Review, 2012, vol. 8, no. 3, August, pp. 247-279. 


\title{
Взаимозависимость политики Европейского центрального банка и финансовой стабильности в зоне евро
}

\author{
Корнелия Салинг
}

Рассматривается влияние политики Европейского центрального банка (ЕЦБ) на финансовую стабильность в еврозоне. Автором обосновывается вывод о том, что в период, предшествующий мировому финансовому кризису 2008-2009 гг. и последующему за ним европейскому долговому кризису, ЕЦБ не уделял достаточного внимания вопросам обеспечения финансовой стабильности. Дана характеристика основных антикризисных мер ЕЦБ и оценивается влияние этих мер на финансовую стабильность. Автор утверждает, что предпринятые меры нестандартной монетарной политики не привели к полной стабилизации региональной европейской финансовой системы даже при заметном восстановлении экономической ситуации. Выявлено несоответствие антикризисных мер ЕЦБ критериям кредитора последней инстанции, что угрожает финансовой стабильности. Проблематичность обеспечения финансовой стабильности в зоне евро осложняется действием единой валюты и единой денежно-кредитной политики при существенной разнородности стран - участниц валютной зоны и наличии внешних факторов риска финансовой стабильности.

Ключевые слова: зона евро; финансовая стабильность; Европейский центральный банк; ценовая стабильность; нестандартные меры денежно-кредитной политики.

Источники:

1. Андронова Н.Э. Место и роль стран БРИКС в формировании новой парадигмы мировой финансовой архитектуры XXI века // Инновационная экономика. 2017. № 1 (10). URL: http://193.232.218.56/web-local/fak/rj/index.php?id=25\&mod=rubric\&mm=30.

2. Архипова В.В. Институциональные источники финансовой нестабильности // Современная Европа. 2016. № 5(71). С. 103-114.

3. Бажан А.И., Гусев К.Н. Европейский центральный банк в условиях финансового кризиса // Современная Европа. 2016. № 3. С. 93-103.

4. Пилипенко О.И. Экономические шоки и циклическое развитие национальных финансовых систем // Вестник РУДН. Сер.: Экономика. 2015. № 1. С. 103-111.

5. Стренина М.А., Салинг К. Проблемы банковского сектора зоны евро в условиях мирового финансового кризиса // Вестник РУДН. Сер.: Экономика. 2016. № 1. С. 32-41.

6. Усоскин В.М. «Нестандартная» монетарная политика: методы и результаты // Деньги и кредит. 2016. № 11. С. 12-18.

7. Яковлев И.А., Кабир Л. С., Никулина С. И., Раков И. Д. Региональные финансовые механизмы и их роль в обеспечении финансовой стабильности (опыт АСЕАН) // Финансовый журнал. 2016. № 5. С. 52-62.

8. Alesina A., Summers L. H. Central Bank Independence and Macroeconomic Performance: Some Comparative Evidence // Journal of Money, Credit and Banking. 1993. Vol. 25. No. 2. P. 151-162.

9. Cross-Border Banking in Europe: Implications for Financial Stability and Macroeconomic Policies / F. Allen, T. Beck, E. Carletti, P. R. Lane, D. Schoenmaker, W. Wagner. L. : Centre for Economic Policy Research, 2011.

10. ECB Unconventional Monetary Policy and the Italian Economy during the Sovereign Debt Crisis / M. Casiraghi, E. Gaiotti, L. Rodano, A. Secchi // International Journal of Central Banking. 2016. Vol. 12. No. 2. P. 269-315.

11. Grauwe P., de. Economics of Monetary Union. $11^{\text {th }}$ ed. Oxford: Oxford University Press, 2016.

12. Ferguson R. W. Should Financial Stability Be an Explicit Central Bank Objective? // Challenges to Central Banking from Globalized Financial Systems: Proc. of the Conference at the IMF (Washington, D.C., September 16-17, 2002). URL: https://www.imf.org/external/pubs/ft/seminar/2002/gfs/eng/ ferguson.pdf.

13. Steinbach A. The Lender of Last Resort in the Eurozone // Common Market Law Review. 2016. Vol. 53. No. 2. P. 361-384. URL: http://ggcpp.nuff.ox.ac.uk/wp-content/uploads/2016/02/Armin-WPThe-Lender-of-Last-Resort-in-the-Eurozone.pdf.

14. Tsionas E. The Euro and International Financial Stability. Springer International Publishing, 2014. Series: Financial and Monetary Policy Studies. Vol. 37.

15. Wall L. D. Central Banking for Financial Stability. Some Lessons from the Recent Instability in the US and Euro Area // Japan Ministry of Finance Public Policy Review. 2012. Vol. 8. No. 3. P. 247-279. 
Сведения об авторе:

Корнелия Салинг, аспирант кафедры международных экономических отношений Контактный телефон: (495) 434-43-15

e-mail: cornelia.sahling@gmail.com
Российский университет дружбы народов 117198, РФ, г. Москва, ул. Миклухо-Маклая, 6

Ссылка для ицитирования:

Sahling C. Interdependence of the European Central Bank's Policy and Financial Stability in the Eurozone // Известия Уральского государственного экономического университета. 2017. № 3 (71). С. 66-76.

For citation:

Sahling C. Interdependence of the European Central Bank's Policy and Financial Stability in the Eurozone. Izvestiya Uralskogo gosudarstvennogo ekonomicheskogo universiteta - Journal of the Ural State University of Economics, 2017, no. 3 (71), pp. 66-76. 